\title{
OBITUARY
}

\section{PROFESSOR J. W. H. EYRE}

PROFESSOR JOHN EYRE attained such commanding rank as a bacteriologist that it is sometimes forgotten that his first interests were in ophthalmology. After qualification from Guy's Hospital in 1893 he became ophthalmic assistant to Brailey and Higgens and it was at this period of his life that he published the results of his work in the bacteriology of the eye, in which he was one of the pioneers, in a series of papers that became classical. His researches were chiefly confined to the bacteriology of the normal conjunctival sac and to conjunctival tuberculosis. He died on February 17, 1944 , at the age of 74 years.

Mr. S. H. Browning writes :-

It can be the good fortune of few to have had as a teacher and friend, a man of the genius, personality and charm of Prof. John Eyre. As a teacher he was outstanding and his wealth of knowledge was always at the service of his colleagues. His especial knowledge of eyes and eye bacteriology was of more than ordinary help to me in starting the Bacteriological Laboratories at Moorfields and his kindly criticism and ever willing help and encouragement will always be remembered with gratitude.

As a brother Mason and a brother "Savage" he was a true example of loyalfriendship.

\section{NOTES}

Princess Tsahai Memorial Hospital Fund

WE have received a letter appealing for funds to found in Ethiopia a hospital with Medical School, library and ambulance services in memory of Princess Tsahai as a token of goodwill from Great Britain to Ethiopia. Princess Tsahai qualified in Nursing at Guy's Hospital and returned to her home to organize a modern medical and nursing service in her own country. Her death, at the age of 22 years, occurred on August 17, 1942.

The appeal has the warm support of the heads of the medical and nursing professions in this country and it goes without saying that British ophthalmology records its sympathy. There must be a great opportunity for preventative ophthalmology in Ethiopia and we wish the appeal to be successful. Further information can be obtained from the Hon. Secretary, Miss E. Sylvia Pankhurst, 3 Charteris Road, Woodford, Essex. 